\title{
1. Sustainability, innovation and entrepreneurship: introduction to the volume
}

\author{
Rolf Wüstenhagen, Sanjay Sharma, \\ Mark Starik and Robert Wuebker ${ }^{1}$
}

\section{OVERVIEW}

Sustainability is back on the global agenda. After intense debates in the late 1970 s and early 1980 s about limits to growth, rising oil prices, forest dieback (Waldsterben) and the like, environmental and social issues received less attention in European public opinion during the 1990s. In the US, the timing was different, with an increasing level of attention to sustainability issues across businesses and non-governmental organizations (NGOs) occurring in the 1990s. With a new focus on climate change, we have recently seen the discussion about sustainable development return with increased intensity. The threat of uncontrolled changes in the atmosphere has led to an unprecedented wave of public attention to environmental challenges. At the same time, there is also increased awareness of social challenges such as high unemployment rates, increasing inequalities and poverty in developing countries. Global policy makers and corporate leaders are expressing the need for action. Governments have started to embark on ambitious emission targets. Corporate sustainability seems to have become a mainstream issue, at least on paper.

At the same time, though, it becomes apparent that the magnitude of the sustainability challenge calls for more than just incremental changes to existing patterns of production and consumption. Just as global greenhouse gas levels have embarked on a steep path of discontinuous change, we seem to be in need of fundamentally new solutions in the way we do business and govern our economies. And even if we succeed in making substantial changes to corporate strategies and consumer behaviour, it seems to be an open question whether this will be successful. John Doerr, a prominent representative from the cradle of American optimism, the venture capital community of Silicon Valley, recently talked about the accelerating 
pace of greentech investments, but at the same time commented that he is afraid that what we do might be 'too little, too late'. ${ }^{2}$ What this shows us is that it is high time for scholars to address the corporate sustainability discourse from an innovation and entrepreneurship angle.

\section{CONCEPTUALIZING SUSTAINABILITY, INNOVATION AND ENTREPRENEURSHIP}

\section{The Corporate Sustainability Perspective: From Environmental Management Systems to Sustainable Business Models}

The field of academic research on corporate sustainability management has gained significant sophistication since the beginnings of what is now the Organizations and the Natural Environment (ONE) division in the Academy of Management. Research on corporate sustainability management, with its interest in the connection between the natural environment and various organizational levels of analyses (individuals, subgroups, organizations, or clusters of organizations) is a relatively recent scholarly phenomenon. In comparison with its sister disciplines of strategy, organizational behaviour, and environmental economics, where research spans decades, its history is relatively brief.

In the early 1980s, firms responded to the growing awareness of the longterm consequences of environmental impact by engaging in corporate greening efforts (Hart, 1997) and implementing environmental policies that in some cases went beyond mere compliance with the law (Marcus, 1980). In the late 1980s, management scholars began to study these firms, developing at first conceptual and then empirical research on the various aspects of organizational greening. Initial descriptive and case-driven work (Buchholz et al., 1992; Starik, 1995) became the touchstones for the evolution of additional theory development and empirical studies (Throop et al., 1993; Hart and Ahuja, 1996; Sharma and Vredenburg, 1998; Dowell et al., 2000).

As befits an evolving field, the theories and paradigms in sustainability management research have drawn from research conducted in the 'home' field of the particular scholar, employing both qualitative and quantitative approaches. Early research on corporate sustainability focused on the individual firm and firm attributes essential to environmental performance, seeking to identify the characteristics and capabilities that enable firms to achieve the best possible environmental performance (Nehrt, 1996) and why some firms comply, and others overcomply, with regulatory requirements (Arora and Gangopadhyay, 1995; Arora and Cason, 1996; Majumdar and 
Marcus, 1998). Early work on corporate sustainability drew heavily on the strategic management literature, arguing that excellence in protecting the environment created new opportunities to achieve competitive advantage through the effective use of firm resources (Hart, 1995; Porter and van der Linde, 1995; Russo and Fouts, 1997; Aragón-Correa and Sharma, 2003). The strategy literature, with its focus on achieving superior relative performance, has been extensively used to address operational issues such as environmental management systems (Welford, 1992; Dyllick and Hamschmidt, 2000; Steger, 2000) and eco-efficiency (Schmidheiny, 1992; Schaltegger and Sturm, 1995). If resources are used both uniquely and effectively it is argued that this leads to increased performance (Elkington, 1994; Sharma and Vredenburg, 1998). Early research focusing on the differentiation of environmental products (Reinhardt, 1998) has evolved to address the more thoroughgoing question of how to enact performance-enhancing sustainability strategies as measured by market efficiency (Dowell et al., 2000) rather than resource efficiency (Hart and Ahuja, 1996).

While research at the level of the firm has provided key insights, this is far from the end of the story (Starik and Marcus, 2000; Starik, 2002). Firms exist in an industry and institutional environment, complete with contextspecific pressures and institutional norms, and sustainable management scholarship took steps to incorporate these facts into theory development and empirical accounts (Hoffmann and Ventresca, 1999; Hoffmann, 2001; Delmas and Terlaak, 2002; Hart and Milstein, 2003; Doh and Guay, 2006). Research on stakeholder influences on corporate sustainability practices (Dyllick, 1989; Pablo et al., 1999; Sharma, 2000; Sharma and Starik, 2004; Sharma and Henriques, 2005) has enriched our understanding of this critical external dimension, describing firms in terms of their relationships in broader social networks. Stakeholder research has recently moved from looking at how firms react to existing external pressure to investigating how proactive management of stakeholder relations can lead to tapping the potential for new innovative ideas. Examples include research on how engagement of stakeholders by the firm may catalyse learning and innovation (Hart and Sharma, 2004), as well as Prahalad and Hart's work on the 'bottom of the pyramid', which attempts to integrate the social equity and ecological dimensions of sustainability (Hart and Christensen, 2002; Prahalad and Hart, 2002; London and Hart, 2004).

Increasing awareness of the magnitude of current sustainability challenges and a more global perspective have led to the emergence of research on the creation and dissemination of clean technology innovation. Despite the sharply increasing levels of public attention for this theme, it has remained somewhat underexplored by academics (for example, Hart and Milstein, 1999; Hawken et al., 1999; McDonough and Braungart, 2002; 
Hall and Vredenburg, 2003; Moore and Wüstenhagen, 2004; Könnölä and Unruh, 2007). This gap in current literature on corporate sustainability management marks the starting-point for this volume.

The research presented in this volume can be described as a shift in corporate sustainability from exploitation to exploration (March, 1991), from environmental management to sustainable entrepreneurship (Schaltegger and Petersen, 2000; Schaltegger, 2002; Mair et al., 2006; Dean and McMullen, 2007) and from eco-efficiency (Ayres, 1995) to clean technology development. This shift in focus suggests increased scope of analysis beyond the largest firms and additional opportunity for personal and scholarly impact. The promise of sustainable entrepreneurship is to apply Schumpeterian-style 'creative destruction' (Hart and Milstein, 1999) to the simultaneous benefit of firms, society and the environment, which may ultimately result in the emergence of sustainable industries (Russo, 2003).

An issue, which has received scant attention by sustainability researchers so far, is the need for financing sustainable innovation and entrepreneurship, for example by means of venture capital (Randjelovic et al., 2003; Moore and Wüstenhagen, 2004; Wüstenhagen and Teppo, 2006).

\section{The Innovation Perspective: Understanding the Emergence of New Markets}

How the emergence of radical innovation can transform an industry has been an important research topic in innovation studies. From this perspective, the move from conventional to sustainable products and services could be interpreted as a discontinuity in the technological trajectory of an industry, leading to a technological paradigm change (Nelson and Winter, 1982; Utterback and Suárez, 1993). The emergence of a new technological paradigm leads to a creative destruction (Schumpeter, 1939) of existing competences, which improves the selection environment for industry outsiders who are more flexible to pursue new opportunities without the liabilities of existing assets (Tushman and Anderson, 1986; Utterback, 1994).

In terms of industry development, a technological paradigm change is usually characterized by a high degree of variation, indicated by a large number of new entrants experimenting with new product designs (Utterback and Suárez, 1993; Metcalfe, 1994). After some time, a dominant design (Utterback and Abernathy, 1975) emerges, marking a shift from variation to selection, marked by industry consolidation and an increasing number of exits. The subsectors of what could be referred to as 'emerging clean technology industries' are currently at different stages of development. For example, while the solar photovoltaic industry has been characterized by a high degree of experimentation and new entries in 2003-05, the 
wind turbine manufacturing industry has started to consolidate in 2002-04, with acquisitions by large incumbent players such as GE and Siemens, and mergers of pioneering firms such as Vestas and NEG Micon (Bear Stearns, 2004; Ernst \& Young, 2006).

Moving from industry to firm level, a stream of literature has investigated ways for firms to address radical innovation. A common feature of this literature is that success stories among large incumbent firms are rare and challenges are numerous (Kanter, 1989; Christensen, 1997; Leifer et al., 2000). Innovation management scholars are drawing diverse conclusions from this insight. On the optimistic end, Leifer et al. (2001) argue that by following seven key strategic imperatives, mature companies may successfully embrace radical innovation and eventually 'outsmart upstarts' (Leifer et al., 2000). For example, they argue that creating a radical innovation hub, acquiring both internal and external resources for the radical innovation project, and accelerating project transition from the lab to a mainstream business unit, will help mature companies to succeed. Similarly, Stringer (2000) lists nine different strategies that successful innovators have used to 'attack the problem', including both organizational aspects such as the creation of informal project laboratories and idea markets, as well as proposals to work with outside venture capitalists, a factor that is also stressed by Chesbrough (2000). Burgelman (1985) provided suggestions for improving corporate venturing, but points out that the inherent tensions in marrying large corporations with radical innovation are unlikely to go away. Consequently, he termed new venture departments 'a design for ambiguity'. Other scholars are more on the sceptical end of the spectrum, such as Dougherty (1995) who suggests that large companies should simply focus on a reflected way of managing their 'core incompetences', or Miles and Covin (2002) who have identified an increasing tendency towards replacing the painful exercise of being innovative within the firm by simply acquiring other firms. Despite these sobering results, there seems to be a consensus that innovation remains a strategic imperative (Stringer, 2000), so large companies have to embark on corporate venturing in one form or another if they want to secure their long-term survival.

Turning from the supply side to the demand side of the picture, Rogers (2001) has pioneered a stream of literature that looks at the diffusion of innovation as an evolutionary adoption process. He argues that the diffusion of innovation follows a typical S-curve, with a small group of innovating customers leading the way, followed by early adopters, early majority, late majority and laggards. Rogers also elaborates on features of innovative products that accelerate diffusion, such as relative advantage (over existing products), compatibility, complexity, trialability and observability. 
Compared to the classical diffusion process, the diffusion of sustainable innovation has some peculiarities (Villiger et al., 2000). As Rennings (2000) argues, eco-innovation is characterized by a double externality. The first part of the externality, technological spillover that prevents the innovator from appropriating the full value of an innovation, is common to any other technological innovation. The second part of the externality is specific to eco-innovation, which is the lack of internalization of environmental cost for incumbent technologies. The presence of external costs has two important effects: it reduces the relative (private) benefit of eco-innovation for customers, and it assigns a role to government to overcome this problem. The former is a significant barrier to customer adoption, the latter introduces an additional challenge to innovating new firms, as large incumbent firms are typically in a better position to influence regulators than are entrepreneurial start-ups.

Finally, many of the critical natural resource industries such as electricity, oil, gas and water are bound to grid infrastructures and subject to long investment cycles, which inherently increases complexity and reduces trialability of new innovative products as two of the key adoption features identified by Rogers (2001).

While innovation scholars have often looked at either the supply side (that is, the influence of radical innovation on firms or industries) or the demand side (that is, the adoption of innovation by customers) of the picture, a full understanding of the transformation process requires an examination of both sides and their interdependencies (Villiger et al., 2000). For example, Bhidé (2006) points out that while many scholars have tried to explain the success of the 'Silicon Valley' model of innovation in the United States by supply-side factors such as government research and development (R\&D), entrepreneurial activity and venture finance, a key additional factor is the willingness of US consumers to buy and try new, innovative products, which Bhidé calls 'venturesome consumption', that is, their willingness to buy and try new, innovative products. More on a macro level, scholars in the evolution of technological systems tradition are taking a similarly integrated approach to studying the emergence of new industries (Jacobsson and Bergek, 2004).

\section{Putting the Pieces Together: Research Themes in Sustainability, Innovation and Entrepreneurship}

Figure 1.1 borrows from both sustainability (Villiger et al., 2000) and innovation (Rogers, 2001) literature to show how the components of this volume are conceptually intertwined. Sustainability, innovation and entrepreneurship is conceptualized as a twofold diffusion process - with 


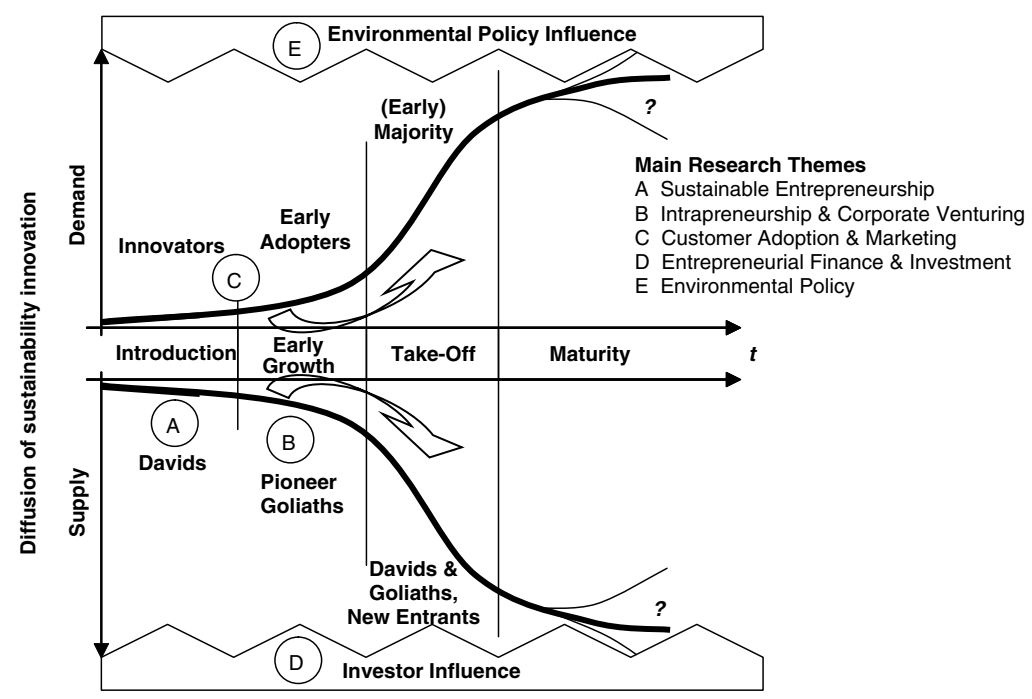

Source: Adapted from Wüstenhagen (2007).

Figure 1.1 Mapping research themes in sustainability, innovation and entrepreneurship

innovation and adoption taking place among both customers and suppliers of sustainable products and services - and being framed by investor and policy influences.

Five main research themes can be identified around the emergence and market penetration of sustainability innovation:

1. the role of 'Davids', or sustainable entrepreneurship;

2. the challenges for 'Goliaths', or large incumbent companies, in pursuing corporate venturing and promoting sustainable intrapreneurship;

3. customer adoption of and marketing for sustainable products and services;

4. the influence of investors on market emergence for sustainable innovation; and

5. elements of an innovation-friendly environmental policy.

These themes will be introduced in the following section, with reference to the contributions made by the chapters of this volume. Subsequently, we shall discuss some of the remaining challenges for further research on sustainability, innovation and entrepreneurship. 


\section{THE CONTRIBUTION OF CHAPTERS IN THIS VOLUME}

\section{Part I: Sustainable Entrepreneurship}

The five chapters in Part I address various aspects of sustainable entrepreneurship. Three of these have a conceptual focus and two have an empirical focus. Based on a literature review of the different streams of environmental, social and sustainable entrepreneurship, Schaltegger and Wagner develop, in Chapter 2, a framework for sustainability management and a positioning matrix of sustainable entrepreneurship. They distinguish different types of sustainability management along two dimensions: first, whether the impact is limited to a small market niche, to a wider mainstream market or to changing market and society at large, and second, the degree of priority of environmental and social issues as business goals. In their view, true sustainable entrepreneurship is characterized by high scores on both axes, that is, the attempt to have an impact on both mainstream market and society, as well as the ambition to link sustainability performance to core business goals. They go on to argue that this differentiates sustainable entrepreneurs from eco-preneurs (or 'bioneers'), for whom sustainability is key, but who are satisfied with addressing niche markets, as well as from sustainability administrators, who lack the ambition to link social and environmental issues to core business goals and competitive advantage.

In Chapter 3, Spence et al., address issues of sustainable entrepreneurship from a conceptual angle as well. They focus on small and medium-sized enterprises (SMEs) and their involvement in sustainable development. They argue that understanding SME approaches to sustainable development is based on an understanding of a set of internal and external features. On one hand, an SME's approach to sustainable development is a function of personal characteristics of the SME's owners/managers, such as their entrepreneurial orientation, vision, openness to change, self-transcendence, sustainability orientation, and perception of ability and competence. On the other, the approach taken depends on the level of stakeholder pressures, and whether those are perceived as opportunity or threat by the SME's owners/managers. Based on a literature review, Spence et al. describe a set of strategic sustainable development activities that SMEs can pursue, ranging from identification of salient stakeholders through various forms of stakeholder communication and cooperation to pursuing a 'going local' strategy with regard to suppliers and/or customers. The final variable in Spence et al.'s suggested model is sustainability performance of SMEs. Here, they suggest a list of quantitative and qualitative indicators to capture 
the direct and indirect benefits of 'going sustainable'. They argue that higher involvement in strategic sustainability activities will lead SMEs to a wider use of non-financial performance indicators, and hence a broader understanding of what performance ultimately means.

As a third contribution to the conceptual discussion of sustainable entrepreneurship, in Chapter 4, Halme et al. focus on business models for material efficiency. The business model concept has originally been developed with a view to explaining new forms of value creation enabled by the internet and the emerging forms of electronic commerce (Timmers, 1999; Afuah and Tucci, 2000) and has only recently been discovered as a unit of analysis by sustainability researchers (Tukker, 2004; Wüstenhagen and Boehnke, 2007). Halme et al. acknowledge that the term 'business model' is somewhat ill-defined, but explore its usefulness in a specific application, namely in the context of material-efficiency services. They distinguish three types of business models for material efficiency (the material service company (MASCO) model, material efficiency as additional service, and material flow management service) and investigate them with regard to four typical components of a business model (customer value, competitive advantage, capabilities required, revenue model). A key common element of the business models that they discuss is that they redefine the traditional borderline between suppliers and customers, just as e-commerce enabled new kinds of value configuration that transcended existing supplier-customer relationships. In their assessment of the feasibility of different business models for material efficiency, they highlight the importance of financing challenges. They conclude that the MASCO model and the 'material efficiency as additional service' model, as other forms of outsourcing, are particularly appropriate for investment projects with sufficient size which address a sidestream of production rather than the customer's core business.

The three conceptual contributions to the entrepreneurship theme are complemented by two empirical papers, reporting on a survey among UK clean technology ventures and a Dutch case study, respectively. In Chapter 5, Dee et al. investigate obstacles to commercialization of clean technology innovation from UK ventures, with a view to developing policy recommendations to overcome those obstacles. Based on a survey among 73 micro-SMEs and nine in-depth case studies, the authors investigate the relevance of various barriers to firm growth, including financial factors, management and organizational factors, and product and market factors. Financing challenges turn out to be of high importance to firms, both with regard to securing funding for R\&D as well as for commercialization. Government grants, personal finance and venture capital are among the most frequently used sources of funding. Another important obstacle to 
growth is establishing contacts with customers, which links to our research theme on customer adoption (see Part III). This is also one of the areas where UK clean technology ventures most frequently seek external advice, be it on conducting market research or in actually accessing potential customers. Overall, the results of Dee et al.'s analysis support this volume's main argument that the key challenge is for sustainability ventures to 'cross the chasm' (Moore, 1991) between laboratory and commercialization, and hence to penetrate the mainstream market 'beyond the eco-niche' (Villiger et al., 2000). Dee et al. conclude by giving a number of policy recommendations for improving the situation of UK clean technology ventures. They argue that government should reconsider its public procurement rules in order to make the $\mathrm{B} 2 \mathrm{G}$ (business-to-government) purchasing process more open to innovative, sustainable products. Another important role for government is in creating standards and facilitating certification procedures for innovative new technologies.

Starting from a sustainable design perspective, Berchicci's Chapter 6 on the challenges of commercializing a radical innovation in the Dutch transportation sector adds some interesting insights to Dee et al.'s chapter. He argues that in the case of Mitka, an innovative three-wheeled bicycle, designers appeared to have 'too much of a good thing', namely too much environmental ambition. By getting carried away by the environmental and design features of their product, they missed important aspects of customer value, and hence the innovation eventually failed. This example provides a nice illustration of Schaltegger and Wagner's argument that sustainable entrepreneurship essentially relies on integrating environmental and social issues into core business goals. Berchicci also points to another interesting link between environmental ambition and success (or failure) of a sustainable innovation, arguing that higher levels of environmental ambition on the part of the design team are likely to result in higher degrees of complexity.

\section{Part II: Sustainable Corporate Venturing and Intrapreneurship}

Sustainable innovation does not just happen in entrepreneurial start-ups, but also within existing firms. This is addressed by the two chapters in Part II.

In Chapter 7, Pichel reports on the results of a major longitudinal analysis among employees of five German companies undergoing introduction of an environmental management system (EMS). Her research interest is to understand whether introduction of an EMS has a positive influence on the contextual, individual and cultural antecedents of ecopreneurship within the firm (defined as proactive environmental behaviour of employees) and on actual behaviour. She concludes that transparency and eco-specific 
training are the two most important predictors of ecopreneurship, confirming earlier work by Ramus and Steger (2000). Interestingly, she could not find a clear positive link between financial incentives and environmental employee behaviour, and even finds some support for a negative relationship between the two. She concludes that an organizational culture that values environmental issues and individual initiative might be more effective in promoting ecopreneurship within the firm than a command-and-control structure coupled with (extrinsic) incentives. However, she also points out that firms should be aware of their organizational culture and adapt their EMS design accordingly. Introducing an EMS that encourages autonomous employee initiative for environmental issues in a firm with a strong hierarchical culture will not work.

Picking up on the theme of intrapreneurhsip for sustainability, Chapter 8 by Martín-Tapia et al. explores the potential of a high performance work system (HPWS) to contribute to proactive environmental management. The term HPWS summarizes a set of human resource management practices aimed at increasing organizational performance, some of which are directly linked to Pichel's findings about factors enhancing ecopreneurship within firms, such as improved internal communication (transparency), participation and extensive training. Martín-Tapia et al. add a new dimension by taking into account the moderating effect of uncertainty. In their empirical survey of Spanish food firms, they can confirm the positive link between an HPWS and proactive environmental management, while the effect of uncertainty seems not to be significant.

\section{Part III: Customer Adoption of and Marketing for Sustainability Innovation}

As we discussed above, an innovation is not successful until it finds a customer. Therefore, research about marketing for and customer adoption of sustainability innovation has been one of the central themes in our call for chapters for this volume. The two chapters in Part III provide particular insights with that respect, one each in a business-to-consumer (B2C) and a business-to-business (B2B) setting.

Kassinis and Soteriou's analysis, in Chapter 9, addresses the relationship between quality, environmental practices and customer satisfaction in a service setting. Based on a survey about hotel services, they argue that environmental practices have a positive mediating influence on the relationship between service quality and customer satisfaction. In other words, signalling environmental practices will increase customer satisfaction beyond standard levels of good quality services. A particularly innovative element of Kassinis and Soteriou's contribution is their methodological approach. 
They use video technology to expose the respondents of their survey to realistic scenarios of the service experience in the hotel. By carefully blending in the environmental features that they try to measure, they avoid some of the social desirability issues that traditional surveys on environmental issues and consumer adoption of sustainability innovation would face.

Vermeulen and Ellersiek, in Chapter 10, look at the adoption of an innovative product in a B2B setting, and do so in a longitudinal analysis from an institutional perspective. Based on extensive qualitative research, they reconstruct the diffusion of an environmental innovation in the concrete industry and how this diffusion process is shaped by institutional forces. Vermeulen and Ellersiek's work adds two important dimensions to the research agenda of customer adoption of sustainability innovation. First, they move from individual adoption decisions to their embeddedness in organizational and institutional environments. Second, they draw our attention to the constraints of mature organizational fields, and especially the power of incumbents, against which new entrants have to struggle in order to get their innovation to market. In their Dutch case, ultimate adoption of the innovation has led to a partial reconfiguration of the organizational field, which has only been possible thanks to a change agent, or 'institutional architect', who bridged the diverging interests of existing actors in the field.

\section{Part IV: Investors and Policy}

The two chapters in Part IV focus on the two final themes that we think should constitute elements of a comprehensive research agenda on sustainability, innovation and entrepreneurship; that is, how the diffusion of sustainability innovation is shaped by investor and policy influences. This to us indicates the need for further research in this area (see the next section).

In Chapter 11, Cañón-de-Francia et al. investigate the linkages between environmental policy and corporate performance by looking at the effect of a specific regulation, the European Pollutant Emission Register (EPER), on the financial performance of affected Spanish firms. They find confirmation for their hypothesis that the public disclosure of environmental information, in this case the presence of polluting firms on an official 'black list' published by the European Union, does have a measurable effect on these firms' shortterm share-price development. While they acknowledge some limitations of their study, their chapter makes two interesting contributions to the debate on sustainability, innovation and entrepreneurship. First, they demonstrate that 'soft', quasi-regulatory policy measures, based on disclosure of information, can indeed provide an incentive for firms to improve their 
environmental performance. Second, they make a methodological contribution by applying event study methodology to sustainability research. A very popular approach in finance research, this methodology makes use of the abundance of financial data available for publicly traded companies to measure market implications of events such as the introduction of a new policy. Cañón-de-Francia et al. contribute to this literature by comparing three different estimation models, namely a traditional market model, a portfolio model and a multivariate regression model (MVRM), where only the last allows them to determine significant negative abnormal returns on the day after publication of the EPER.

Finally, Chapter 12 by Bürer and Wüstenhagen brings us back to the core of this volume's focus, namely sustainable innovation and entrepreneurship. They explore the link between energy policy and investor decisions to fund clean technology ventures. Policy is important since the energy industry is a typical example of a heavily regulated industry, and particularly large incumbent energy firms have developed significant expertise in influencing the political framework through non-market strategies. New entrants to the energy industry, such as clean energy technology ventures, are also exposed to regulatory risk (and opportunity), but they do not have the means to engage in non-market strategies to a similar extent as large incumbent firms. And yet, the success of investments in these firms significantly depends on managing regulatory risk. Little is known empirically about how venture investors perceive energy policy risk and what they do to manage it. Based on a survey among 60 venture capital firms in Europe and North America, Bürer and Wüstenhagen attempt to close this gap. They build on their survey data to develop a typology of regulatory risk management strategies adopted by these investment firms.

\section{FURTHER RESEARCH}

While the chapters in this volume provide fresh and rewarding insights into the complex relationships between sustainability, innovation and entrepreneurship, the individual works also point to opportunities for further research, which we would like to complement by addressing some of the overall open issues. To begin, a suggestion that applies across the different themes discussed in this volume, there is scope for extending research on sustainable innovation and entrepreneurship to new industry sectors (such as resource extraction, other forms of manufacturing not studied in these chapters, distribution and other services, including information systems and security) and geographical regions (including emerging and developing countries). 
We would also like to point out that several of the chapters in this volume focus on environmental aspects of sustainability, while there is certainly scope for more work on the social aspects of sustainability. In a comprehensive research agenda, social and environmental sustainability should be integrated, researched jointly, and given roughly equal attention.

\section{Sustainable Entrepreneurship}

One of the remaining questions in research on sustainable entrepreneurship is to enhance our understanding of the profile of sustainable entrepreneurs, or probably more appropriately, entrepreneurial teams. Are there specific sources of entrepreneurial talent for sustainability-related ventures? What is the right mix of environmental and social vision (or ambition) versus pure business orientation?

Speaking of the entrepreneurs themselves, while the 'traits' approach to strategic entrepreneurship fell out of favour in the 1980s and 1990s, given the unique features of sustainable entrepreneurship, identifying themes and commonalities of the personal and professional characteristics of these entrepreneurs may be advantageous in both understanding and advancing this phenomenon. In addition, exploring the life-cycle aspects of these entrepreneurs compared to others would also be interesting, since sustainability entrepreneurs, with their presumed deeply held social and environmental values, might be more prone to staying with their ventures longer than entrepreneurs with economic orientations only. They may also be far less likely to hand over their successful ventures or to abandon their less-than-successful businesses, even when walking away may be the most prudent strategy.

It is also important to take a process perspective on sustainable entrepreneurship. As in the case of 'conventional' ventures, what it takes for a sustainable venture to be successful changes over time. We know from conventional entrepreneurship research that entrepreneurs are typically best at managing a venture at a certain stage of development, while changes ('exits') occur once the venture has grown beyond this stage. Zooming in at the exit stage of sustainable entrepreneurial ventures may be an interesting field for further research, since the value captured by conventional entrepreneurs is relatively easily transferable to new owners/managers, while this may not be the case for the social and environmental aspects of value created by a sustainable entrepreneurial venture.

Another issue relates to the inherent complexity of sustainability ventures - what does this imply for the skills and capabilities of successful sustainable entrepreneurs? Perhaps this topic could be addressed by studying how these entrepreneurs conduct strategic planning, compared to other entrepreneurs and other business leaders, and how the sustainable 
entrepreneurs implement and evaluate their strategies, particularly to ensure that their operations are indeed sustainable.

Given the evolving nature of both sustainability technologies and indicators, from micro to macro, these activities may be especially challenging for sustainable entrepreneurs. While challenges, obstacles, constraints and externalities may be intriguing sustainable entrepreneurship research topics, opportunities, synergies and solutions for sustainable entrepreneurs also hold promise. These may involve the full range of actual and potential stakeholders, in addition to customers and suppliers, including owners, family and network members, investors, partners, managers, employees, consultants, competitors, distributors, franchisees, NGOs (including academics), industry associations and the several levels of government. Focusing particularly on entrepreneurs in NGOs, one especially interesting research topic might be identifying and highlighting those operating in more 'social sustainability' NGOs whose main mission is to advocate for human rights and poverty reduction, for example, but who are also attempting to make environmental changes within their own organizations, such as increasing energy efficiency or reducing the use of toxic materials. Similarly, entrepreneurs in environmental NGOs may have developed some interesting approaches to social issues, such as community participation and physical health of the disadvantaged (Husted et al., 2007).

Some interesting opportunities for further research arise at the interface of gender studies and sustainable innovation and entrepreneurship. For example, the social construction of new energy technologies provides evidence for gender differences (Wajcman, 1991, 2000; Cockburn and Ormrod, 1993). A stronger role for female entrepreneurs may be a road not only to overcoming social inequalities, but perhaps also towards environmental sustainability. It would also be worth exploring whether women are more inclined to start social entrepreneurial ventures, and if so, why.

The perspective of business models for sustainability ventures also provides opportunities for further research. What characterizes successful business models for entrepreneurial ventures in key sustainability areas, such as energy, transportation or water? Given that sustainable innovation is characterized by a double-externality problem (Rennings, 2000), and hence there is an important interface to policy making, how can notoriously resource-constrained start-ups take this into account and manage regulatory risks and opportunities?

\section{Sustainable Corporate Venturing and Intrapreneurship}

Sustainable innovation occurs not only in garage ventures, but also within the boundaries of large firms. However, the chapters in this book addressing 
these issues demonstrate that it is anything but trivial to enhance proactive environmental employee behaviour or the creation of new ventures within the institutional and cultural constraints of incumbent firms - in other words, we are facing a 'battle between organizational genetics and accelerating change'. ${ }^{3}$ When it comes to sustainability ventures, this general observation from corporate venturing research is aggravated by the values that come into play in the context of environmental and social issues. An interesting research avenue here might be to ask how corporate venturing arms of incumbent firms deal with the combined conflict that sustainable innovation creates with an incumbent firm's market- and non-market (or regulatory) strategy, and whether this negatively influences their chances of success. This inherent conflict can also be taken to the individual level, where it is interesting to deepen our understanding of the personal profiles of successful promoters of sustainability innovation within incumbent firms. Finally, as research in this volume shows, successful ways of promoting cultural change in large corporations and increasing absorptive capacity are a remaining challenge, perhaps particularly so in old and powerful industries such as oil, electricity and automotive.

\section{Customer Adoption of and Marketing for Sustainability Innovation}

In terms of marketing-related research on sustainability innovation, we are facing two main challenges - dealing with the social desirability biases in responses around social and environmental issues, and dealing with the novelty of the products and services at hand - which limit the validity of conventional market research. Therefore, a prime concern in this area is finding valid methods to deal with 'true' customer preferences around new and sustainable products. More sophisticated survey designs, like Kassinis and Soteriou's video simulation presented in Chapter 10, or using methodologies such as conjoint experiments (Sammer and Wüstenhagen, 2006), can help mitigate one or both of these issues. A possible extension might be to introduce test markets for sustainability innovation, for example, in the form of local niche experiments around sustainable transportation (Hoogma et al., 2002).

Another interesting avenue for further research is exploring the uncharted territory between $\mathrm{B} 2 \mathrm{C}$ and $\mathrm{B} 2 \mathrm{~B}$ marketing that characterizes many energy-related consumer decisions, as for example in the case of distributed energy systems or renewable heating technologies, where individual house owners take their decisions influenced by professional advisers such as architects and installers (Känzig and Wüstenhagen, 2006), and hence in a setting that has some but not all the features of a typical buying centre as we know it from organizational buying behaviour. 
Finally, similar to what was said above about gender issues on the supply side of innovation, there are opportunities to investigate the demand side of sustainable innovation from a gender perspective. While men are often portrayed as being overrepresented in the adoption of technological innovation, we know from consumer surveys that women often have a strong concern about environmental issues. How does this concern translate into actual purchasing and investment decisions, particularly if decisions are taken jointly in a buying group setting as in the residential energy example mentioned above?

\section{Investors and Environmental Policy}

Moving from the core issues of supply of and demand for sustainability innovation to the forces that frame this market, we would like to highlight a number of research opportunities around investor and policy influences.

When it comes to financing sustainability innovation, the role of cleantech investors, from business angels through venture capitalists to private equity firms, deserves scholarly attention. It would be particularly interesting to enhance our understanding of the motivation of these investors and their interaction with entrepreneurs. Given the recent move from 'irrational austerity to (ir)rational exuberance' (Wüstenhagen, 2005) among cleantech venture capital investors, there is a case for looking at cleantech investments from a behavioural finance perspective and trying to track and measure some of the path dependencies and herding phenomena that occur. Doing this will also shed light on the question of how these early-stage investors create value between actually improving the performance of their portfolio firms and/or managing expectations of other investors.

Speaking more broadly about the topic of sustainable finance (Jeucken, 2001; Labatt and White, 2002), this may be an aspect of sustainable innovation and entrepreneurship that is primed for growth in the very near future. From the various kinds of funds, through new security instruments, to the greening of entire professions, such as bankers, insurers, brokers and realtors, sustainable entrepreneurs are poised to help this field emerge as they continue to develop good ideas that demand financial resources for their realization. Researchers can suggest various channels for this development, identifying how sustainability has taken hold in other operationsorientated sectors and professions and how the combination between sustainable entrepreneurs and finance can help advance sustainability both within these areas and, if successful, more broadly through both developed and developing societies.

In the environmental policy realm, a shifting focus would be welcomed from looking at compliance to further understanding how environmental 
policy can support innovation (Hemmelskamp et al., 2000). A key prerequisite for accomplishing this research task is to come to a diffentiated understanding of how large incumbent firms ('Goliaths') and small entrepreneurial firms ('Davids') are affected by environmental policy changes or new regulatory instruments (Wüstenhagen, 1998). The link between policies and venture investors may again be interesting to look at, since private investment monies can strongly leverage the effect of new policies.

\section{CONCLUSIONS}

The magnitude of the environmental and social challenges that our planet is facing calls for a dramatic shift towards new solutions. This volume highlights the central and critical role of entrepreneurship and innovation in moving us towards a sustainable future via business models that incorporate social equity, ecosystem stewardship, and design of environmentally and socially beneficial products, services and processes. By entrepreneurship we refer not only to newly founded firms but also to corporate entrepreneurs that spark organizational creativity and innovation and thus teach corporate 'elephants how to dance' (Kanter, 1989) in a sustainable world. Academic research can play an important role in helping us understand the constraints and challenges that entrepreneurs, corporate managers, policy makers, investors and consumers face in moving towards sustainability. It can also highlight positive examples and point to the multitude of new business opportunities that arise. Ultimately, though, we also need to move from analysis to action and from concept to reality. We hope that readers will find the contributions in this book valuable and inspiring for their journey towards sustainability.

\section{NOTES}

1. The authors wish to acknowledge the financial contributions from the oikos Foundation for Economy and Ecology, the Swiss National Science Foundation, and the University of St. Gallen. We are also grateful for intellectual contributions made by the participants of the GRONEN 2006 conference during the plenary sessions. We thank Josef Känzig for the great deal of effort he put into helping us to organize the conference and manage the paper selection process. We would also like to thank the members of the GRONEN 2006 scientific committee for their help in the review process. All remaining errors are the authors' sole responsibility.

2. See www.ted.com/index.php/speakers/view/id/116.

3. Comment made by Mike Russo at the final panel of the GRONEN 2006 conference in St. Gallen (Switzerland), 12 July 2006. 


\section{REFERENCES}

Afuah, A. and Tucci, C. (2000), Internet Business Models and Strategies: Text and Cases, New York: McGraw-Hill Higher Education.

Aragón-Correa, J.A. and Sharma, S. (2003), 'A contingent resource-based view of proactive corporate environmental strategy', Academy of Management Review, 28(1): 71-88.

Arora, S. and Cason, T.N. (1996), 'Why do firms volunteer to exceed environmental regulations? Understanding participation in EPA's 33/50 program', Land Economics, 72(4): 413-32.

Arora, S. and Gangopadhyay, S. (1995), 'Toward a theoretical model of voluntary overcompliance', Journal of Economic Behavior and Organization, 28: 289-309.

Ayres, R.U. (1995), Achieving Eco-efficiency in Business, New York: World Business Council for Sustainable Development, United Nations Environment Programme (UNEP).

Bear Stearns (2004), 'The Future of Power Equipment', European Equity Research Report, 24 November, London.

Bhidé, A. (2006), 'Venturesome consumption, innovation and globalisation', paper presented at the CESifo and Centre on Capitalism and Society conference, Venice, 21-22 July, http://www.cesifo.de/link/vsi06_ep_bhide.pdf.

Buchholz, R.A., Marcus, A.A. and Post, J.E. (1992), Managing Environmental Issues: A Casebook, Englewood Cliffs, NJ: Prentice-Hall.

Burgelman, R.A. (1985), 'Managing the new venture division: research findings and implications for strategic management', Strategic Management Journal, 6: 39-54.

Chesbrough, H.W. (2000), 'Designing corporate ventures in the shadow of private venture capital', California Management Review, 42(3): 31-49.

Christensen, C. (1997), The Innovator's Dilemma, Boston, MA: Harvard Business School Press.

Cockburn, C. and Ormrod, S. (1993), Gender and Technology in the Making, London: Sage.

Dean, T.J. and McMullen, J.S. (2007), 'Toward a theory of sustainable entrepreneurship: reducing environmental degradation through entrepreneurial action', Journal of Business Venturing, 22(1), 50-76.

Delmas, M.A. and Terlaak, A.K. (2002), 'The institutional context of environmental voluntary agreements', in Hoffman, A.J. and Ventresca, M.J. (eds), Organizations, Policy, and the Natural Environment: Institutional and Strategic Perspectives, Stanford, CA: Stanford University Press, pp. 346-66.

Doh, J.P. and Guay, T.R. (2006), 'Corporate social responsibility, public policy, and NGO activism in Europe and the United States: an institutional-stakeholder perspective', Journal of Management Studies, 43(1): 47-73.

Dougherty, D. (1995), 'Managing your core incompetencies for corporate venturing', Entrepreneurship Theory and Practice, 19(3), 113-35.

Dowell, G., Hart, S. and Yeung, B. (2000), 'Do corporate global environmental standards create or destroy market value?', Management Science, 46(8): 1059-74.

Dyllick, T. (1989), Management der Umweltbeziehungen: Öffentliche Auseinandersetzungen als Herausforderung (Management of environmental relations: public conflicts as a challenge), Wiesbaden: Gabler Verlag.

Dyllick, T. and Hamschmidt, J. (2000), Wirksamkeit und Leistung von Umweltmanagementsystemen: Eine Untersuchung von ISO 14001-zertifizierten Unternehmen in der Schweiz (Effectiveness and performance of environmental 
management systems: an empirical analysis of ISO 14001-certified firms in Switzerland), Zurich: VdF Hochschulverlag.

Elkington, J. (1994), 'Towards the sustainable corporation: win-win-win business strategies for sustainable development', California Management Review, 36(3): 90-100.

Ernst \& Young (2006), TransAction Erneuerbare Energien: Marktüberblick und M\&A-Aktivitäten 2001-2006 (TransAction renewable energies: Market Survey and M\&A activities 2001-2006), Berlin, July.

Hall, J. and Vredenburg, H. (2003), 'The challenges of innovating for sustainable development', MIT Sloan Management Review, Fall: 61-8.

Hart, S. (1995), 'A natural resource-based view of the firm', Academy of Management Review, 20: 986-1014.

Hart, S. (1997), 'Beyond greening: strategies for a sustainable world', Harvard Business Review, 75(1): 66-76.

Hart, S. and Ahuja, I.G. (1996), 'Does it pay to be green? An empirical examination of the relationship between emission reduction and firm performance', Business Strategy and the Environment, 5(1): 530-37.

Hart, S. and Christensen C.M. (2002), 'The great leap: driving innovation from the base of the pyramid', MIT Sloan Management Review, Fall: 51-6.

Hart, S. and Milstein, M.B. (1999), 'Global sustainability and the creative destruction of industries', MIT Sloan Management Review, 41(1), 23-33.

Hart, S. and Milstein, M.B. (2003), 'Creating sustainable value', Academy of Management Executive, 17(2), 56-67.

Hart, S. and Sharma, S. (2004), 'Engaging fringe stakeholders for competitive imagination', Academy of Management Executive, 18(1), 7-18.

Hawken, P., Lovins, A. and Lovins, L.H. (1999), Natural Capitalism: Creating the Next Industrial Revolution, Boston, MA: Little, Brown.

Hemmelskamp, J., Rennings, K. and Leone, F. (2000), Innovation-Oriented Environmental Regulation: Theoretical Approaches and Empirical Analysis, Heidelberg: Physica.

Hoffman, A.J. (2001), From Heresy to Dogma: An Institutional History of Corporate Environmentalism, Stanford, CA: Stanford University Press.

Hoffman, A.J. and Ventresca, M.J. (1999), 'The institutional framing of policy debates: economics versus the environment', American Behavioral Scientist, 42(8): 1368-92.

Hoogma, R., Kemp, R., Schot, J. and Truffer, B. (2002), Experimenting for Sustainable Transport: The Approach of Strategic Niche Management, London and New York: Spon Press.

Husted, B., Sharma, S. and Starik, M. (2007), 'Organizations and the sustainability mosaic: crafting long-term ecological and societal solutions', in Sharma, S., Starik, M. and Husted, B. (eds), Organizations and the Sustainability Mosaic, Cheltenham, UK and Northampton, MA: Edward Elgar, pp. 18-19.

Jacobsson, S. and Bergek, A. (2004), 'Transforming the energy sector: the evolution of technological systems in renewable energy technology', in Jacob, K., Binder, M. and Wieczorek, A. (eds), Governance for Industrial Transformation: Proceedings of the 2003 Berlin Conference on the Human Dimensions of Global Environmental Change, Berlin: Environmental Policy Research Centre, pp. 208-36.

Jeucken, M. (2001), Sustainable Finance and Banking, London: Earthscan.

Känzig, J. and Wüstenhagen, R. (2006), 'Understanding strategic choices for sustainable consumption: the case of residential energy supply', in Charter, M. and 
Tukker, A. (eds), Sustainable Consumption and Production: Opportunities and Challenges, Proceedings of the Launch conference of the Sustainable Consumption Research Exchange (SCORE) Network, Wuppertal, Germany, 23-25 November, www.score-network.org.

Kanter, R.M. (1989), When Giants Learn to Dance, New York: Simon \& Schuster.

Könnölä, T. and Unruh, G.C. (2007), 'Really changing the course: the limitations of environmental management systems for innovation', Business Strategy and the Environment (in press).

Labatt, S. and White, R.R. (2002), Environmental Finance, Hoboken, NJ: J. Wiley.

Leifer, R., McDermott, C.M., O'Connor, G.C., Peters, L.S., Rice, M. and Veryzer, R.W. (2000), Radical Innovation: How Mature Companies Can Outsmart Upstarts, Boston, MA: Harvard Business School Press.

Leifer, R., O'Connor G.C. and Rice, M. (2001), 'Implementing radical innovation in mature firms: the role of hubs', Academy of Management Executive, 15(3): 102-13.

London, T. and Hart, S.L. (2004), 'Reinventing strategies for emerging markets: beyond the transnational model', Journal of International Business Studies, 35(5): 350-70.

Mair, J., Robinson, J. and Hockerts, K. (2006), Social Entrepreneurship, Basingstoke, UK: Palgrave Macmillan.

Majumdar, S.K. and Marcus, A.A. (1998), 'Do Environmental Regulations Retard Productivity? Evidence from U.S. Electric Utilities', Working Paper (Faculty) 1, University of Michigan Business School.

March, J.G. (1991), 'Exploration and exploitation in organizational learning', Organization Science, 2(1): 71-87.

Marcus, A. (1980), Promise and Performance: Choosing and Implementing an Environmental Policy, Westport, CT: Greenwood-Praeger.

McDonough, W. and Braungart M. (2002), Cradle to Cradle: Remaking the Way We Make Things, New York: North Point.

Metcalfe, J.S. (1994), 'Evolutionary economics and technology policy', Economic Journal, 104(425): 931-44.

Miles, M.P. and Covin, J.G. (2002), 'Exploring the practice of corporate venturing: some common forms and their organisational implications', Entrepreneurship Theory and Practice, 26(1): 21-40.

Moore, B. and Wüstenhagen, R. (2004), 'Innovative and sustainable energy technologies: the role of venture capital', Business Strategy and the Environment, 13: 235-45.

Moore, G.A. (1991), Crossing the Chasm, New York: HarperCollins.

Nehrt, C. (1996), 'Timing and intensity effects of environmental investments', Strategic Management Journal, 17(7): 535-47.

Nelson, R. and Winter, S. (1982), An Evolutionary Theory of Economic Change, Cambridge, UK: Cambridge University Press.

Pablo, A., Sharma, S. and Vredenburg, H. (1999), 'Corporate environmental responsiveness strategies: the importance of issue interpretation and organizational context', Journal of Applied Behavioral Science, 35(1): 87-108.

Porter, M.E. and van der Linde, C. (1995), 'Green and competitive: ending the stalemate', Harvard Business Review, 73(5): 120-34.

Prahalad, C.K. and Hart, S.L. (2002), 'The fortune at the bottom of the pyramid', Strategy and Business, 26: 54-67.

Ramus, C. and Steger, U. (2000), 'The roles of supervisory support behaviours and environmental policy in employee "ecoinitiatives" at leading-edge European companies', The Academy of Management Journal, 43(4), 605-26. 
Randjelovic, J., O'Rourke, A.R. and Orsato, R.J. (2003), 'The emergence of green venture capital', Business Strategy and the Environment, 12(4): 240-53.

Reinhardt, F.L. (1998), 'Environmental product differentiation: implications for corporate strategy', California Management Review, 40(4): 43-73.

Rennings, K. (2000), 'Redefining innovation - eco-innovation research and the contribution from ecological economics', Ecological Economics, 32(2), 319-32.

Rogers, E.M. (2001), Diffusion of Innovations, New York: Free Press.

Russo, M.V. (2003), 'The emergence of sustainable industries: building on natural capital', Strategic Management Journal, 24: 317-31.

Russo, M.V. and Fouts, P.A. (1997), 'A resource-based perspective on corporate environmental performance and profitability', Academy of Management Journal, 40(3): 534-59.

Sammer, K. and Wüstenhagen, R. (2006), 'The influence of eco-labelling on consumer behaviour - results of a discrete analysis for washing machines', Business Strategy and the Environment, 15, 185-9.

Schaltegger, S. (2002), 'A framework for ecopreneurship - leading bioneers and environmental managers to ecopreneurship', Greener Management International (GMI), 38, Summer: 45-58.

Schaltegger, S. and Petersen, H. (2000), Ecopreneurship: Konzept und Typologie (Entrepreneurship: concept and typology), Lüneburg/Luzern: CSM/RIOManagementforum.

Schaltegger, S. and Sturm, A. (1995), Öko-Effizienz durch Öko-Controlling: Zur praktischen Umsetzung von EMAS und ISO 14000 (Eco-efficiency by eco-controlling: on the implementation of EMAS and ISO 14000), Zurich and Stuttgart: Verlag der Fachvereine/Schaefer Poeschel.

Schmidheiny, S. (1992), Changing Course: A Global Business Perspective on Development and the Environment, Cambridge, MA: MIT Press.

Schumpeter, J.A. (1939), Business Cycles: A Theoretical, Historical, and Statistical Analysis of the Capitalist Process, New York: Free Press.

Sharma, S. (2000), 'Managerial interpretations and organizational context as predictors of corporate choice of environmental strategy', Academy of Management Journal, 43(4): 681-97.

Sharma, S. and Henriques, I. (2005), 'Stakeholder influences on sustainability practices in the Canadian forest products industry', Strategic Management Journal, 26: $159-80$.

Sharma, S. and Starik, M. (eds) (2004), Stakeholders, the Environment and Society, Cheltenham, UK and Northampton, MA, USA: Edward Elgar.

Sharma, S. and Vredenburg, H. (1998), 'Proactive corporate environmental strategy and the development of competitively valuable organizational capabilities', Strategic Management Journal, 19(8): 729-53.

Starik, M. (1995), 'Research on organizations and the natural environment: some paths we have traveled, the "field" ahead', in Collins, D. and Starik, M. (eds), Research in Corporate Social Performance and Policy - Sustaining the Natural Environment: Empirical Studies on the Interface between Nature and Organizations, Greenwich, CT: JAI Press, pp. 1-42.

Starik, M. (2002), 'Childhood's end? Sustaining and developing the evolving field of organizations and the natural environment', in Sharma, S. and Starik, M. (eds), Research in Corporate Sustainability: The Evolving Theory and Practice of Organizations and the Natural Environment, Cheltenham, UK and Northampton, MA: Edward Elgar, pp. 321-2. 
Starik, M. and Marcus, A.A. (2000), 'Introduction to the Special Research Forum on the Management of Organizations in the Natural Environment: a field emerging from multiple paths, with many challenges ahead', Academy of Management Journal, 43(4): 539-47.

Steger, U. (2000), 'Environmental management systems: empirical evidence and further perspectives', European Management Journal, 18(1): 23-37.

Stringer, R. (2000), 'How to manage radical innovation', California Management Review, 42(4): 70-88.

Throop, G.M., Starik, M. and Rands, G.P. (1993), 'Sustainable strategy in a greening world: integrating the natural environment into strategic management', in Shrivastava, P., Huff, A. and Dutton, J. (eds), Advances in Strategic Management, Greenwich, CT: JAI Press, pp. 63-92.

Timmers, P. (1999), Electronic Commerce, New York: John Wiley \& Sons.

Tukker, A. (2004), 'Eight types of product-service system: eight ways to sustainability? Experiences from SusProNet: Business Strategy and the Environment, 13, 246-60.

Tushman, M.L. and Anderson, P. (1986), 'Technological discontinuities and organizational environments', Administrative Science Quarterly, 31: 439-65.

Utterback, J. (1994), Mastering the Dynamics of Innovation, Boston, MA: Harvard Business School Press.

Utterback, J.M. and Abernathy, W.J. (1975), 'A dynamic model of product and process innovation', Omega, 3(6): 639-56.

Utterback, J.M. and Suárez, F.F. (1993), 'Innovation, competition, and industry structure', Research Policy, 22: 1-21.

Villiger, A., Wüstenhagen, R. and Meyer, A. (2000), Jenseits der Öko-Nische (Beyond the eco-niche), Basel: Birkhäuser.

Wajcman, J. (1991), Feminism Confronts Technology, University Park, PA: Pennsylvania State University Press.

Wajcman, J. (2000), 'Reflections on gender and technology studies: in what state is the art?', Social Studies of Science, 30(3), 447-67.

Welford, R. (1992), 'Linking quality and the environment: a strategy for the implementation of environmental management systems', Business Strategy and the Environment, 1(1), 25-34.

Wüstenhagen, R. (1998), 'Greening Goliaths versus multiplying Davids', Institute for Economy and the Environment at the University of St. Gallen (IWÖ) Discussion Paper No. 61, University of St. Gallen.

Wüstenhagen, R. (2005), 'Venture capital funding and sustainability innovation: far from irrational exuberance', Oekologisches Wirtschaften, Special Issue Nachhaltiges Gründen, 2/2005.

Wüstenhagen, R. (2007), 'Venturing for Sustainable Energy', unpublished synopsis paper of postdoctoral research thesis (Habilitation), University of St. Gallen.

Wüstenhagen, R. and Boehnke, J. (2007), 'Business models for sustainable energy', in Tukker, A., Charter, M., Vezzoli, C., Sto, E. and Andersen, M.M. (eds), System Innovation for Sustainability: Perspectives on Radical Changes to Sustainable Consumption and Production (SCP), Sheffield: Greenleaf, (forthcoming).

Wüstenhagen, R. and Teppo, T. (2006), 'Do venture capitalists really invest in good industries? Risk-return perceptions and path dependence in the emerging European energy VC market', International Journal of Technology Management, 34(1/2): 63-87. 
Rolf Wüstenhagen, Sanjay Sharma, Mark Starik, and Robert Wuebker - 9781848441552 Downloaded from PubFactory at 04/26/2023 11:54:14AM via free access 